\title{
AKREDITASI MADRASAH
}

\author{
Mulyono \\ Dosen pada program studi PGMI dan PAI UIN Malang
}

\begin{abstract}
Quantitatively, amount of madrasah which increasing since decade 1990-an, hence policy require to be strategic to the make-up of its quality. One of the effort with believed to become strategic step develop;build quality of madrasah is require to perform of accreditation of madrasah periodical. performed of the accreditation program expected can reach standard is quality of which is specified and in turn can improve quality of good madrasah at quality of quality and also institute all educative participant to be able to reach efficacy of education. Accreditation system play role which do not only is important, but strategic also. That strategic role for example is, First: giving comprehensive information to society (stakeholders) concerning certain madrasah. Second, as starting point all educationist and all builder of madrasah in analysing and giving solution to problem of faced by madrasah. Third, as a means of operation of quality. Accurate information which got from accreditation will become starting point to pertinent madrasah to conduct internally of review able to be made by directive in makeup of quality.
\end{abstract}

\section{Keywords: Accreditation, Madrasah}

\section{A. Pendahuluan}

Keberadaan madrasah di Indonesia sejak dekade 1990-an betulbetul menunjukkan eksistensi yang terus menguat, baik secara kuantitatif maupun kualitatif. Secara kuantitatif, data Departemen Agama RI tahun 2000-2001 menyebutkan bahwa saat ini terdapat 36.105 madrasah yang tersebar di seluruh wilayah Indonesia dengan rincian: Madrasah Ibtidaiyah (MI) berjumlah 22.035 buah; Madrasah Tsanawiyah (MTs) berjumlah 10.365 buah; dan Madrasah Aliyah (MA) mencapai 3.705 buah. Dari jumlah tersebut, murid madrasah saat ini mencapai 5.459 .370 orang dengan perincian sebagai berikut: MI menampung 2.998.573 murid atau 10,65\% dari jumlah seluruh anak usia 7-12 tahun (27.684.191). Dari jumlah itu MIN menampung 284.521 murid atau 1,1\% dan MIS menampung 2.704 .052 
Mulyono - Akreditasi Madrasah

murid atau 9,64\%. Angka Partisipasi Kasar (APK) pada MI adalah 10,65\%, yaitu 1,01\% pada MIN dan 9.64\% MIS.(Mastuki, 2001:35).

Pembaharuan di bidang pendidikan madrasah dilakukan terusmenerus agar mampu menghadapi berbagai tantangan sesuai perkembangan zaman dalam era reformasi dan demokratisasi pendidikan. Tantangan yang dihadapi sistem pendidikan meliputi persoalan-persoalan pemerataan, mutu, relevansi dan efisiensi pendidikan. Salah satu upaya bersama yang diyakini mampu memacu dan membangun keunggulan adalah perlu diadakannya akreditasi madrasah secara berkala. Dengan diadakannya program akreditasi tersebut diharapkan dapat mencapai standar kualitas yang ditetapkan dan pada gilirannya mampu mendongkrak keunggulan madrasah, baik pada keunggulan kelembagaan maupun keunggulan para peserta didik untuk dapat mencapai keberhasilan pendidikan.

Sebagaimana yang dikatakan salah satu pejabat Depag Pusat, Moh. Irfan (2001:19), di dalam menentukan kualitas suatu lembaga pendidikan, sistem akreditasi memainkan peranan yang tidak hanya penting, tetapi juga strategis. Peran strategis itu antara lain, pertama: memberikan informasi yang komprehensif kepada masyarakat (stakeholders) mengenai madrasah tertentu. Dengan informasi hasil akreditasi tersebut masyarakat memperoleh gambaran tentang kekurangan, kelebihan, peluang, dan ancaman yang dihadapi madrasah. Kedua, sebagai titik tolak para ahli pendidikan dan para pembina madrasah dalam menganalisis dan memberikan solusi terhadap masalah-masalah yang dihadapi madrasah. Dengan demikian, pembinaan yang dilakukan terhadap madrasah akan selalu kontekstual dan tepat sasaran. Ketiga, sebagai alat pengendalian kualitas. Dengan akreditasi yang komprehensif akan didapatkan peta madrasah dari segi kualitasnya. Ini tidak hanya penting bagi para pengambil kebijakan, tetapi juga sangat bermanfaat bagi madrasah-madrasah bersangkutan. Informasi akurat yang didapat dari akreditasi akan menjadi titik tolak bagi madrasah bersangkutan untuk melakukan internal review yang dapat dijadikan patokan dalam peningkatan kualitas.

Penyelenggaraan akreditasi madrasah merupakan kebutuhan bersama, baik pemerintah, masyarakat, maupun bagi madrasah itu sendiri. Pada hakekatnya tujuan akhir dari penyelenggaraan akreditasi madrasah berupa peningkatan mutu madrasah khususnya mutu lulusan dapat tercapai sebagaimana yang diharapkan (Depag, 2005:27-29). Terkait dengan 
Mulyono - Akreditasi Madrasah

permasalahan tersebut dalam artikel ini penulis mengkaji secara mendalam tentang: bagaimana kebijakan dan pelaksanaan akreditasi madrasah?

\section{B. Kebijakan Akreditasi Madrasah}

Undang-Undang Nomor 20 Tahun 2003 tentang Sistem Pendidikan Nasional pasal 60 menegaskan bahwa: (1) Akreditasi dilakukan untuk menentukan kelayakan program dan satuan pendidikan pada jalur pendidikan formal dan nonformal pada setiap jenjang dan jenis pendidikan; (2) Akreditasi terhadap program dan satuan pendidikan dilakukan oleh Pemerintah dan/atau lembaga mandiri yang berwenang sebagai bentuk akuntabilitas publik; (3) Akreditasi dilakukan atas dasar kriteria yang bersifat terbuka; (4) Ketentuan mengenai akreditasi sebagaimana dimaksud dalam ayat (1), ayat (2), dan ayat (3) diatur lebih lanjut dengan Peraturan Pemerintah. (UU No. 20/2003:39).

Penyelenggaraan akreditasi sebagai salah satu kegiatan peningkatan mutu di bidang pendidikan, pada hakekatnya ialah agar penyelenggaraan pendidikan dapat mencapai standar kualitas yang ditetapkan dan pada gilirannya peserta didik dapat mencapai keberhasilan baik dalam penguasaan ilmu pengetahuan, ketrampilan maupun dalam pembentukan kerpibadian.

Perlu diupayakan penyelenggaraan akreditasi yang sesuai dengan paradigma baru dalam penyelenggaraan akreditasi, di antaranya adalah tidak lagi membedakan antara lembaga negeri dan swasta, mendayagunakan keterlibatan dan peran serta masyarakat, serta prinsip keterbukaan.

Madrasah sebagai bagian dari sistem pendidikan nasional dituntut untuk selalu berupaya meningkatkan kualitas dalam penyelenggaraan pendidikan, hingga dapat menghasilkan lulusan yang berkualitas, mampu bersaing serta mampu menghadapi tantangan zaman. Penyelenggaraan pendidikan yang menghasilkan lulusan bermutu rendah sebenarnya merupakan pemborosan waktu, tenaga dan biaya. Oleh karena itu, penyelenggaraan akreditasi madrasah, sebagai upaya pengendalian mutu, baik melalui sistem penilaian hasil belajar, penerapan kurikulum, sarana, tenaga kependidikan, maupun melalui pengaturan sistem belajar mengajar adalah sebagai suatu keharusan.(Depag, 2005:4-5).

Pemerintah Pemerintah Nomor 25 Tahun 2000 tentang Kewenangan Pemerintah dan Kewenangan Propinsi sebagai Daerah Otonom, telah memuat secara tegas kewenangan pemerintah pusat dan 
Mulyono - Akreditasi Madrasah

kewenangan daerah dalam bidang pendidikan. Berdasarkan kebutuhan akan pentingnya peningkatan kualitas madrasah secara sistematis serta kebijakan tentang otonomi pendidikan, maka pemerintah dalam hal ini Diknas dan Depag telah membuat suatu perubahan dalam konteks penilaian kualitas pendidikan, melalui perbaikan/revisi dan pengembangan pedoman akreditasi sekolah dan madrasah.

Menurut Irfan (2001:19), selama ini akreditasi yang dilakukan cenderung masih berkisar pada bidang-bidang yang bersifat kuantitatif dan administratif. Dalam visitasi, yang merupakan salah satu komponen penting dalam kegiatan akreditasi, kondisi riil madrasah hanya dilihat dari sisi administratif. Hal ini memberikan informasi yang bersifat statis karena dinamika proses belajar-mengajar itu. Akreditasi yang melulu berfokus pada masalah administratif bukan hanya gagal memberikan informasi komprehensif kepada masyarakat, tetapi juga memberikan informasi tidak lengkap kepada para ahli pendidikan dan pembina madrasah. Solusi-solusi yang diajukan pun kemudian sering tidak sejalan dengan masalah riil yang dihadapi oleh madrasah. Dalam hal ini, akreditasi harus mencakup bidangbidang kualitatif.

Menurut Qodri A. Azizy (2005:iii-iv), dengan motivasi untuk meningkatkan kualitas, termasuk efektivitas dan efisiensi, penyelenggaraan pendidikan madrasah, pelaksanaan akreditasi madrasah perlu dan harus diatur sedemikian rupa, sehingga dapat mewadahi hasrat untuk menunjukkan kinerja madrasah ke arah yang lebih baik. Karena pertama, akreditasi dapat mendorong madrasah memenuhi akuntabilitas publik terhadap penyelenggaraan pendidikannya. Hal ini disebabkan karena madrasah secara moral memiliki tanggung jawab secara langsung terhadap masyarakat sekitarnya mengenai pelaksanaan program pendidikannya. Kedua, akreditasi madrasah dapat menjadi ukuran keberhasilan atau tidaknya pengelola madrasah, dan di mana letak kekurangan yang terjadi selama ini. Ketiga, akreditasi madrasah dapat membantu pengelola madrasah untuk lebih terfokus dalam tugas pengelolaan madrasah.

Sedang pejabat Depag Pusat lain, Aziz (2005:v) mengatakan bahwa akreditasi madrasah diselenggarakan atas dasar pertimbangan bahwa upaya meningkatkan madrasah adalah upaya meningkatkan kualitas para lulusannya, sehingga dapat memiliki basis ilmu pengetahuan dan moral yang diperlukan dalam menghadapi masa depannya. Oleh karena itu penyelenggaraan akreditasi madrasah merupakan kebijakan penting 
Mulyono - Akreditasi Madrasah

dilakukan oleh Departemen Agama, khususnya Direktorat Madra sah dan PAI di Sekolah Umum - Direktorat Jenderal Kelembagaan Agama Islam, dalam memotret kinerja madrasah dalam kerangka peningkatan mutu penyelenggaraan dan pelayanan pendidikan.

Beberapa pemikiran dan pendapat di atas, nampaknya ada satu kesepakatan bahwa salah satu kebijakan yang sangat strategis untuk memotivasi, mendorong, dan membangun keunggulan madrasah yang sebagian besar berstatus swasta adalah perlunya pelaksanaan akreditasi madrasah secara periodik. Hal ini juga didukung data lapangan, sebagaimana yang diungkap oleh Drs. H. Moh. Zannur Habib (hasil wawancara, Jum'at: 09 Februari 2007), selaku Ketua Yayasan Almaarif Singosari Kabupaten Malang sebagai pengganti Drs. KH. Tolhah Hasan (Mantan Menag) sebagai berikut:

Menurut hemat saya, program yang paling strategis dan mendorong sekolah dan madrasah LP Ma'arif terpacu untuk meningkatkan mutu adalah adanya akriditasi sekolah dan akreditasi madrasah. Dalam hal pelaksanaan akreditasi madrasah memang agak tertinggal dibanding dengan sekolah-sekolah yang dibawah pembinaan Diknas. Diknas sudah sejak 1982 menyelenggarakan akreditasi sekolah, sedang di lingkungan Depag Kabupaten Malang baru menyelenggarakan akreditasi madrasah pada tahun 1992. Akreditasi madrasah memiliki banyak pengaruh. Karena dengan point-point yang dinilai dalam akreditasi akan mempengaruhi terhadap kewenangan dalam penyelenggaraan ujian. Dengan peringkat Disamakan, Diakui dan Terdaftar pada penilian akreditasi dulu dan sekarang dengan peringkat Tipe A, Tipe B dan Tipe C; maka untuk dapat menyelenggarakan ujian sendiri minimal harus berada pada peringkat "Diakui" atau "Tipe B". Maka dengan adanya akreditasi madrasah, setiap madrasah berjuang keras agar mencapai peringkat yang terbaik yaitu Tipe A, dan minimal mencapai Tipe B. Apabila madrasah hanya mencapai peringkat Terdaftar atau Tipe C maka berakibat sekolah/madrasah tidak dapat menyelenggarakan ujian sendiri dan akhirnya ujian digabung dengan sekolah/madrasah lain sehingga hal ini menjadi gengsi madrasah/sekolah menurun. Menurunnya gengsi madrasah/sekolah akan berakibat menurunnya jumlah peserta didik. Dengan hemat saya, akreditasi itulah yang betul-betul 
Mulyono - Akreditasi Madrasah

memacu sekolah dan madrasah berjuang untuk meningkatkan mutu.

Data di atas juga dikuatkan hasil wawancara dengan Moh. Nur Hasan Muslih, BA. selaku Wakil Ketua Pimpinan LP Ma'arif Cabang Kabupaten Malang sekaligus Pembina Yayasan An-Nur Bululawang Malang (Wawancara, Kamis, 05 april 2005), yang sejak periode 1980-an sebagai assessor di sekolah-sekolah Ma'arif wilayah Jawa Timur, sebagai berikut:

Dengan akreditasi madrasah dapat memacu pengelola madrasah untuk meningkatkan mutu pendidikan. Dengan istilah lain, tanpa akreditasi madrasah, pengelola tidak akan berusaha keras. Dengan adanya akreditasi, pengelola madrasah akan terdorong untuk bekerja keras minimal memenuhi item-item dalam akreditasi. Karena bagi madrasah yang tidak terakreditasi artinya skor penilaian di bawah 351 maka madrasah tersebut akan kehilangan haknya sebagai penyelenggara pendidikan. Mereka harus bergabung dengan madrasah lain dalam segala hal tidak hanya ujian nasional saja tetapi termasuk penggunaan nama madrasah juga harus bergabung. Artinya hak-hak sebagai pengelola madrasah sudah dicabut oleh pemerintah. Hal ini dapat dibayangkan bagaimana pihak yayasan atau pengelola madrasah yang sudah mengelola madrasah 20 tahun kemudian gara-gara tidak terakreditasi hak mereka sebagai pengelola madrasah dicabut, tentunya sangat sedih dan malu. Maka dari itu akreditasi berposisi sebagai pendorong dan pemacu agar madrasah kerja keras sekaligus akreditasi sebagai kartu mati bagi madrasah yang tidak mampu memenuhi komponen-komponen akreditasi minimal pada peringkat C. Dengan demikian akreditasi madrasah merupakan langkah strategis untuk mendorong madrasah mencapai keunggulan sesuai dengan item-item yang ada dalam penilaian akreditasi.

Undang-Undang Republik Indonesia Nomor 20 Tahun 2003 tentang Sistem Pendidikan Nasional Bab XVI pasal 60 tentang akreditasi dan Peraturan Pemerintah Republik Indonesia Nomor 19 Tahun 2005 tentang Standar Nasional Pendidikan serta kebijakan-kebijakan Departemen 
Mulyono - Akreditasi Madrasah

Agama, organisasi maupun para pengelola dan pelaku pendidikan di daerah sebagaimana diungkapkan data diatas, nampaknya saling menguatkan untuk menyatukan langkah bahwa upaya untuk memacu, mendongkak dan membangun keunggulan madrasah, salah satunya melalui pelaksanaan akreditasi madrasah yang bersifat terbuka, transfaran, akuntabilitas, adil baik madrasah negeri maupun madrasah swasta serta mencakup komponen-komponen tidak hanya yang bersifat administratif namun juga mencakup komponen kualitatif dan budaya/kultur madrasah.

\section{Pelaksanaan Akreditasi Madrasah}

\section{Pengertian}

Secara terminologi akreditasi didefinisikan sebagai suatu proses penilaian kualitas dengan menggunakan kriteria baku mutu yang ditetapkan dan bersifat terbuka. Dalam konteks akreditasi madrasah dapat diberikan pengertian sebagai suatu proses penilaian kualitas madrasah, baik madrasah negeri maupun madrasah swasta dengan menggunakan kriteria baku mutu yang ditetapkan oleh pemerintah atau lembaga akreditasi. Hasil penilaian tersebut selanjutnya dijadikan dasar untuk memelihara dan meningkatkan kualitas penyelenggaraan dan pelayanan pendidikan lembaga yang bersangkutan. (Depag, 2005:5-6).

\section{Tujuan}

Tujuan akreditasi madrasah adalah untuk memperoleh gambaran keadaan dan kinerja madrasah dan untuk menentukan tingkat kelayakan suatu madrasah dalam menyelenggarakan pendidikan, sebagai dasar yang dapat digunakan sebagai alat pembinaan dan pengembangan, dalam rangka meningkatkan mutu pendidikan di madrasah. (Depag, 2005: 6).

\section{Fungsi}

Akreditasi madrasah memiliki beberapa fungsi sebagai berikut:

1) Perlindungan Masyarakat (Quality Assurance). Maksudnya agar masyarakat memperoleh jaminan tentang kualitas pendidikan madrasah yang akan dipilihnya, sehingga terhindar dari adanya praktek yang tidak bertanggungjawab.

2) Pengendalian Mutu (Quality Control). Maksudnya agar madrasah mengetahui akan kekuatan dan kelemahan yang dimilikinya, sehingga dapat menyusun perencanaan pengembangan secara berkesinambungan.

3) Pengembangan Mutu (Quality Improvement). Maksudnya agar madrasah merasa terdorong dan tertantang untuk selalu 
Mulyono - Akreditasi Madrasah

mengembangkan dan mempertahankannya kualitas serta berupaya menyempurnakan dari berbagai kekurangan. (Depag, 2005: 6).

\section{Dasar Hukum}

Bagian penting dari terwujudnya standar nasional pendidikan maka pemerintah melakukan akreditasi pada lembaga pendidikan, yang dalam pembahasan ini lebih diarahkan pada akreditasi madrasah dengan landasan hukum UU No. 20 Tahun 2003 tentang Sisdiknas Bab XVI pasal 60, juga pada Peraturan Pemerintah Republik Indonesia Nomor 19 Tahun 2005 tentang Standar Nasional Pendidikan Bab XIII tentang Akreditasi pada pasal 86, 87, 88 .

\section{Sasaran}

Sesuai dengan amanat yang tertuang dalam UU No. 20 Tahun 2003 tentang Sisdiknas dan Undang-Undang Nomor 25 Tahun 2000 tentang Program Pembangunan Nasional (Propenas), bahwa perlu adanya keterlaksanaan pengembangan sistem akreditasi satuan pendidikan formal dan nonformal secara adil dan merata, baik negeri maupun swasta, maka satuan pendidikan di lingkungan Departemen Agama pada jalur formal yang menjadi sasaran akreditasi adalah: (1) Madrasah Ibtidaiyah Negeri dan Swasta; (2) Madrasah Tsanawiyah Negeri dan Swasta; dan Madrasah Aliyah Negeri dan Swasta. (Depag, 2005:7).

\section{Persyaratan}

Untuk memperoleh pengakuan status dan tingkat kelayakan madrasah melalui akreditasi, sekurang-kurangnya satuan pendidikan madrasah harus telah memenuhi persyaratan sebagai lembaga penyelenggara pendidikan, yaitu:

1) Tersedianya komponen penyelenggaraan pendidikan dan pengajaran pada satuan pendidikan, yaitu: (a) Kepala Madrasah; (b) Pendidik dan Tenaga kependidikan, yang terdiri dari sekurangkurangnya guru setiap kelas bagi Madrasah Ibtidaiyah, seorang guru untuk masing-masing mata pelajaran bagi Madrasah Tsanawiyah dan Madrasah Aliyah; (c) Siswa sekurang-kurangnya 10 orang setiap tingkatan; (d) Kurikulum yang diterapkan; (e) Ruang belajar; (f) Buku pelajaran, peralatan dan media pendidikan yang diperlukan; (g) Sumber dana tetap.

2) Penyelenggara pendidikan, baik itu dari pemerintah maupun dari masyarakat. Adapaun penyelenggaraan pendidikan dari 
Mulyono - Akreditasi Madrasah

masyarakat harus berbentuk yayasan atau organisasi sosial yang berbadan hukum.

3) Telah memiliki piagam terdaftar atau izin operasional penyelenggaraan madrasah dari instansi yang berwenang. (Depag, 2005:7-8).

\section{Penilaian}

Untuk menilai mutu madrasah dalam menghasilkan lulusan yang berkualitas, komponen penting yang dijadikan sasaran penilaian dalam akreditasi madrasah adalah Proses Belajar Mengajar (PBM), Sumber Daya, Manajemen, Kultur dan Lingkungan Madrasah.

Tabel 1. Komponen dan Bobot Penilaian Akreditasi

\begin{tabular}{|c|l|c|}
\hline NO. & \multicolumn{1}{|c|}{ KOMPONEN } & BOBOT (\%) \\
\hline 1. & Proses Belajar Mengajar & $35 \%$ \\
\hline 2. & Sumber Daya & $25 \%$ \\
\hline 3. & Manajemen & $23 \%$ \\
\hline 4. & Kultur dan Lingkungan Madrasah & $17 \%$ \\
\hline \multicolumn{2}{|c|}{ Total } & $100 \%$ \\
\hline
\end{tabular}

\section{Prosedur dan Pelaksanaan}

1) Tahapan Kegiatan. Kegiatan akreditasi madrasah dibagi dalam tiga tahapan, yaitu tahap persiapan, tahap pelaksanaan dan serta tahap penetapan peringkat akreditasi.

2) Kegiatan Kunjungan (Visitasi). Kegiatan kunjungan (visitasi) dilakukan dalam rangka klarifikasi data tertuang dalam instrumen akreditasi madrasah serta untuk mengetahui secara langsung kinerja madrasah.

3) Hasil Penilaian dan Peringkat Akreditasi: (a) Hasil penilaian kinerja suatu madrasah diperoleh dari hasil isian kuesioner para responden dan hasil penilaian/pengamatan dari Tim Penilai yang ditunjuk oleh Dewan Akreditasi Madrasah. Hasil akhir penilaian ditentukan melalui sidang Tim Penilai dan Dewan Akreditasi Madrasah tingkat Kabupaten/Kota atau tingkat Propinsi. Jika masih terdapat perbedaan atau belum diperoleh kesepakatan dalam penentuan hasil akhir penilaian, maka Tim Penilai dapat melakukan verifikasi kembali terhadap madrasah yang bersangkutan. (b) Hasil akhir penilaian tersebut akan menjadi bahan pertimbangan dan sebagai dasar dalam penetapan peringkat akreditasi suatu madrasah. (c) Penentuan status dan peringkat dirumuskan sebagai berikut: (1) Terakreditasi dengan peringkat A (Sangat Baik/Unggul) diberikan 
Mulyono - Akreditasi Madrasah

kepada madrasah yang memperoleh jumlah nilai rata-rata antara 451-500. (2) Terakreditasi dengan peringkat B (Baik) diberikan kepada madrasah yang memperoleh jumlah nilai rata-rata antara 401-450. (3) Terakreditasi dengan peringkat C (Cukup) diberikan kepada madrasah yang memperoleh jumlah nilai rata-rata antara 351-400. (4) Bagi madrasah yang hasil akreditasinya kurang dari C dinyatakan tidak terakreditasi. Untuk lebih jelasnya, status atau peringkat akreditasi yang diberlakukan adalah sebagai berikut:

Tabel 2. Peringkat dan Kualifikasi Akreditasi

\begin{tabular}{|c|l|c|}
\hline Status/Peringkat & \multicolumn{1}{|c|}{ Kualifikasi } & $\begin{array}{c}\text { Jumlah } \\
\text { Nilai/Skor }\end{array}$ \\
\hline A & Sangat Baik/Unggul & $451-500$ \\
\hline B & Baik & $401-450$ \\
\hline C & Cukup & $351-400$ \\
\hline
\end{tabular}

(Sumber: Depag, 2005:20-22)

\section{Organisasi}

1) Struktur Organisasi

Untuk menjamin keberhasilan dan keberlanjutan kegiatan akreditasi madrasah serta menghasilkan penilaian yang obyektif dan adil dalam memperoleh layanan pendidikan, perlu dibentuk Dewan Akreditasi Madrasah (DAM). Dewan Akreditasi Madrasah tersebut merupakan lembaga atau badan non-struktural dan bersifat independen yang berada di tingkat pusat, propinsi dan kabupaten/kota. Pembentukan Dewan Akreditasi Madrasah diatur dengan ketentuan sebagai berikut:

a. Dewan Akreditasi Madrasah (DAM) Nasional yang berkedudukan di Departemen Agama Pusat dibentuk oleh Direktur Jenderal Kelembagaan Agama Islam, Departemen Agama RI.

b. Dewan Akreditasi Madrasah (DAM) Propinsi yang berkedudukan di Kantor Wilayah Departemen Agama Propinsi dibentuk oleh Kepala Kanwil Depag Propinsi.

c. Dewan Akreditasi Madrasah (DAM) Kabupaten/Kota dibentuk oleh Kepala Kandepag Kabupaten/Kota. 
Mulyono - Akreditasi Madrasah

Susunan organisasi DAM terdiri dari Ketua merangkap anggota, Sekretaris merangkap anggota, dengan beberapa anggota yang jumlahnya disesuaikan dengan kondisi dan kebutuhan.

Keanggotan DAM berasal dari unsur pemerintah, pakar pendidikan dan akreditasi yang independen, tokoh masyarakat yang memahami dan concern terhadap pendidikan, praktisi pendidikan, dan pihak yang dianggap cakap dalam bidang keahliannya, serta pengawas pendidikan agama Islam. Diupayakan ketua tidak berasal dari Pejabat Struktural. Masa jabatan DAM dalam satu periode 4 (empat) tahun dan dapat diangkat kembali untuk satu periode berikutnya. Adapun dalam pelaksanaan tugasnya sehari-hari, DAM memiliki sekretariat.

2) Tugas dan Fungsi

a. Dewan Akreditasi Madrasah (DAM) Nasional: (1) Merumuskan kebijakan yang berkenaan dengan akreditasi madrasah. (2) Mensosialisasikan kebijakan dan perangkat akreditasi madrasah. (3) Memantau dan mengevaluasi pelaksanaan akreditasi secara nasional. (4) Memberikan bimbingan dan bantuan teknis kepada pelaksana akreditasi di tingkat propinsi dan di tingkat kabupaten/kota. (5) Melaporkan hasil akreditasi madrasah secara nasional.

b. Dewan Akreditasi Madrasah (DAM) Propinsi: (1) Melakukan sosialisasi kebijakan dan koordinasi pelaksanaan akreditasi madrasah. (2) Menyusun perencanaan akreditasi madrasah Madrasah Aliyah. (3) Menyiapkan dan membentuk Tim Penilai (assessor) akreditasi Madrasah Aliyah. (4) Melakukan verifikasi dan validasi data yang disajikan oleh Madrasah Aliyah yang akan diakreditasi. (5) Mengusulkan kepada Kanwil Depag Propinsi tentang penetapan status akreditasi dengan rekomendasi kepada Madrasah Aliyah yang diakreditasi oleh Tim Penilai (assesor). (6) Mengusulkan penerbitan publikasi hasil akreditasi kepada Kanwil Depag Propinsi. (7) Melaporkan hasil akreditasi madrasah secara berkala kepada Kepala Kanwil Depag Propinsi.

c. Dewan Akreditasi Madrasah (DAM) Kabupaten/Kota: (1) Melakukan sosialisasi kebijakan dan koordinasi pelaksanaan akreditasi madrasah. (2) Menyusun perencanaan akreditasi 
Mulyono - Akreditasi Madrasah

Madrasah Ibtidaiyah dan Tsanawiyah. (3) Menyiapkan dan membentuk Tim Penilai (assessor) akreditasi Madrasah Ibtidaiyah dan Tsanawiyah. (4) Melakukan verifikasi dan validasi data yang disajikan oleh Madrasah Ibtidaiyah dan Tsanawiyah yang akan diakreditasi. (5) Mengusulkan kepada Kepala Kanwil Depag Propinsi melalui Kandepag Kabupaten/Kota tentang penetapan status akreditasi dan rekomendasi kepada Madrasah Ibtidaiyah dan Tsanawiyah yang diakreditasi oleh Tim Penilai (assesor). (6) Melaporkan hasil akreditasi madrasah secara berkala kepada Kepala Kandepag Kabupaten/Kota.(Depag, 2005:24-26).

\section{Pelaporan Dan Publikasi}

1) Pelaporan. Pelaporan merupakan suatu keharusan dalam pelaksanaan akreditasi madrasah, mengingat kegiatan akreditasi merupakan kegiatan yang berkesinambungan dan berkelanjutan. Ada tiga bentuk pelaporan dalam penyelenggaraan akreditasi madrasah yaitu: Laporan Tingkat Nasional, Laporan Tingkat Propinsi dan Laporan Tingkat Kabupaten.

2) Publikasi. Publikasi hasil akreditasi madrasah merupakan bentuk pertanggungjawaban kegiatan akreditasi madrasah kepada masyarakat luas, sehingga masyarakat memiliki gambaran yang jelas dan adil terhadap madrasah karena penilaian tersebut dilakukan secara profesional dan dengan pendekatan ilmiah yang dapat dipertanggungjawabkan. Untuk publikasi secara nasional, Departemen Agama akan menerbitkan data base tentang akreditasi secara nasional untuk semua jenjang pendidikan MI, MTs dan MA. Sedangkan di tingkat propinsi Kanwil Depag Propinsi dapat menerbitkan hasil akhir dari penyelenggaraan akreditasi Madrasah Aliyah; dan di tingkat Kabupaten/Kota, Kandepag Kabupaten/Kota dapat menerbitkan hasil akhir dari penyelenggaraan akreditasi Madrasah Ibtidaiyah dan Tsanawiyah. Materi dari publikasi tersebut dapat dikembangkan seluas-luasnya, namun tetap disesuaikan dengan kebutuhan.(Depag, 2005:30). 
Mulyono - Akreditasi Madrasah

\section{Alur Pelaksanaan Akreditasi Madrasah}

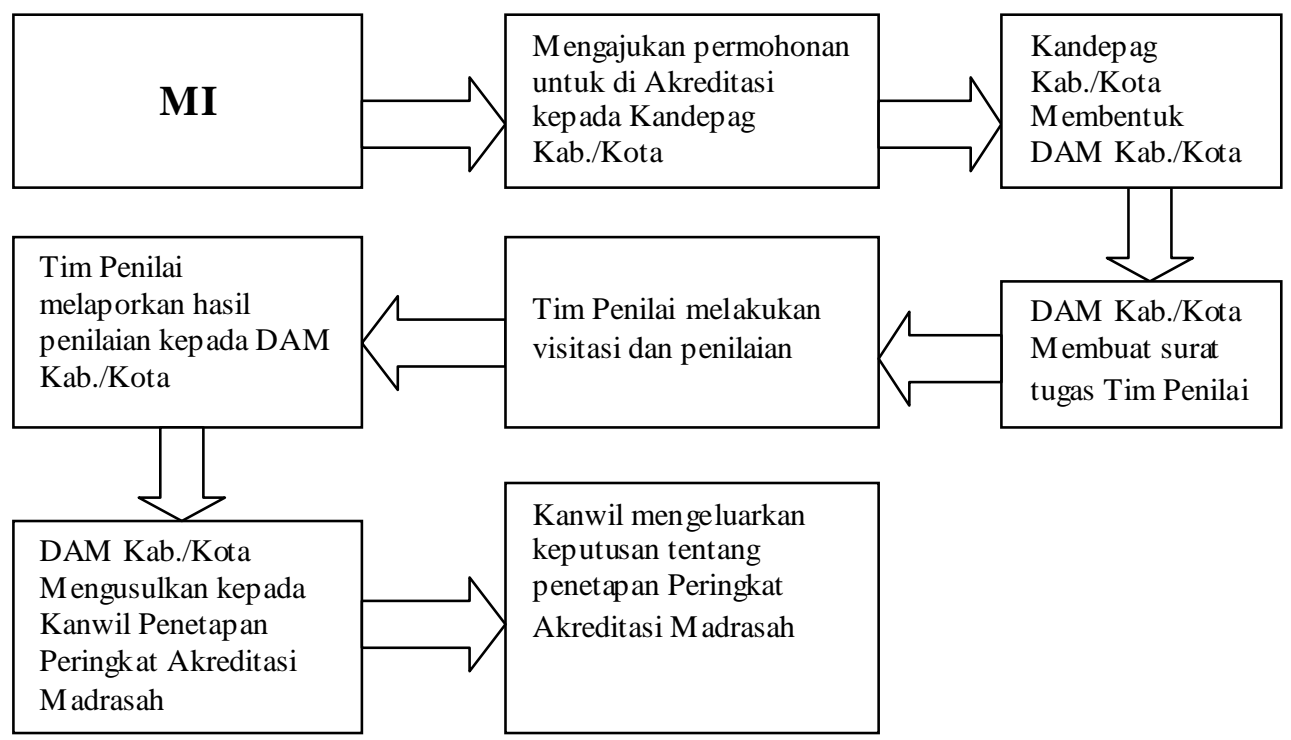

Gambar 1. Alur Pelaksanaan Akreditasi Madrasah Tingkat MI

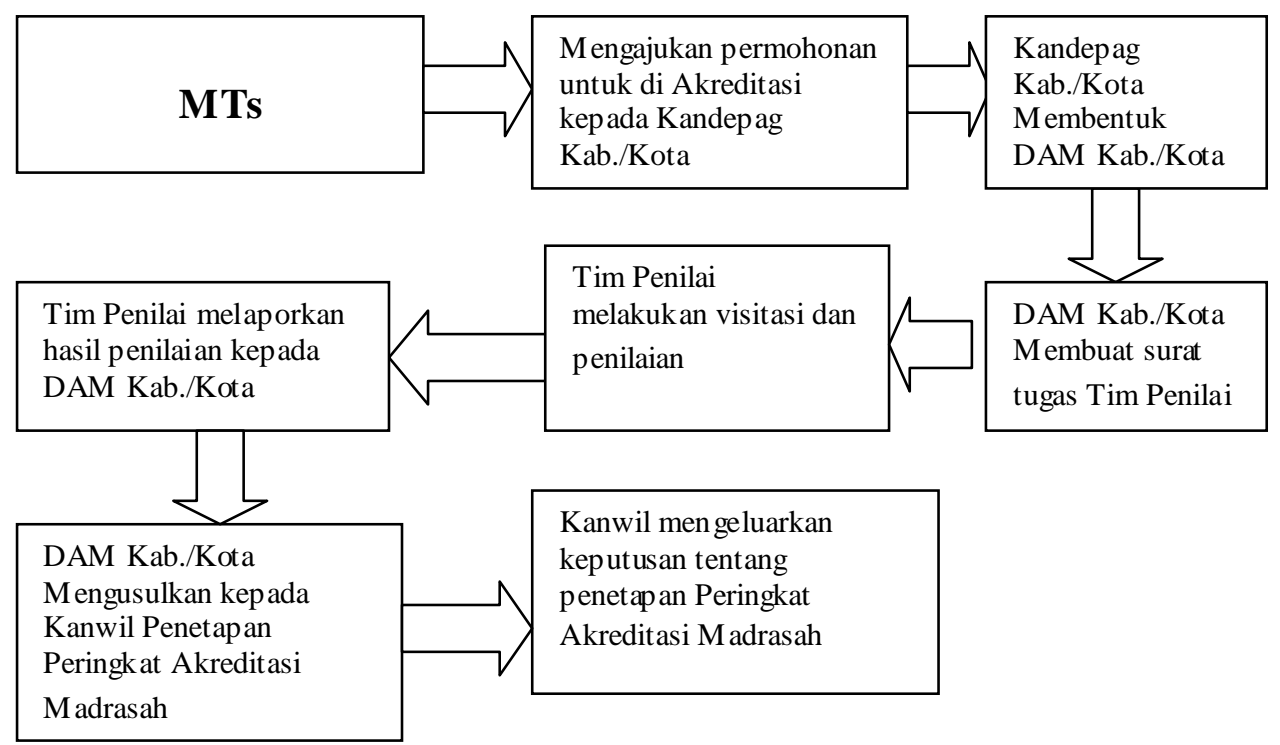

Gambar 2. Alur Pelaksanaan Akreditasi Madrasah Tingkat MTs

188 Madrasah, Vol.Il No.2 Januari - Juni 2010 


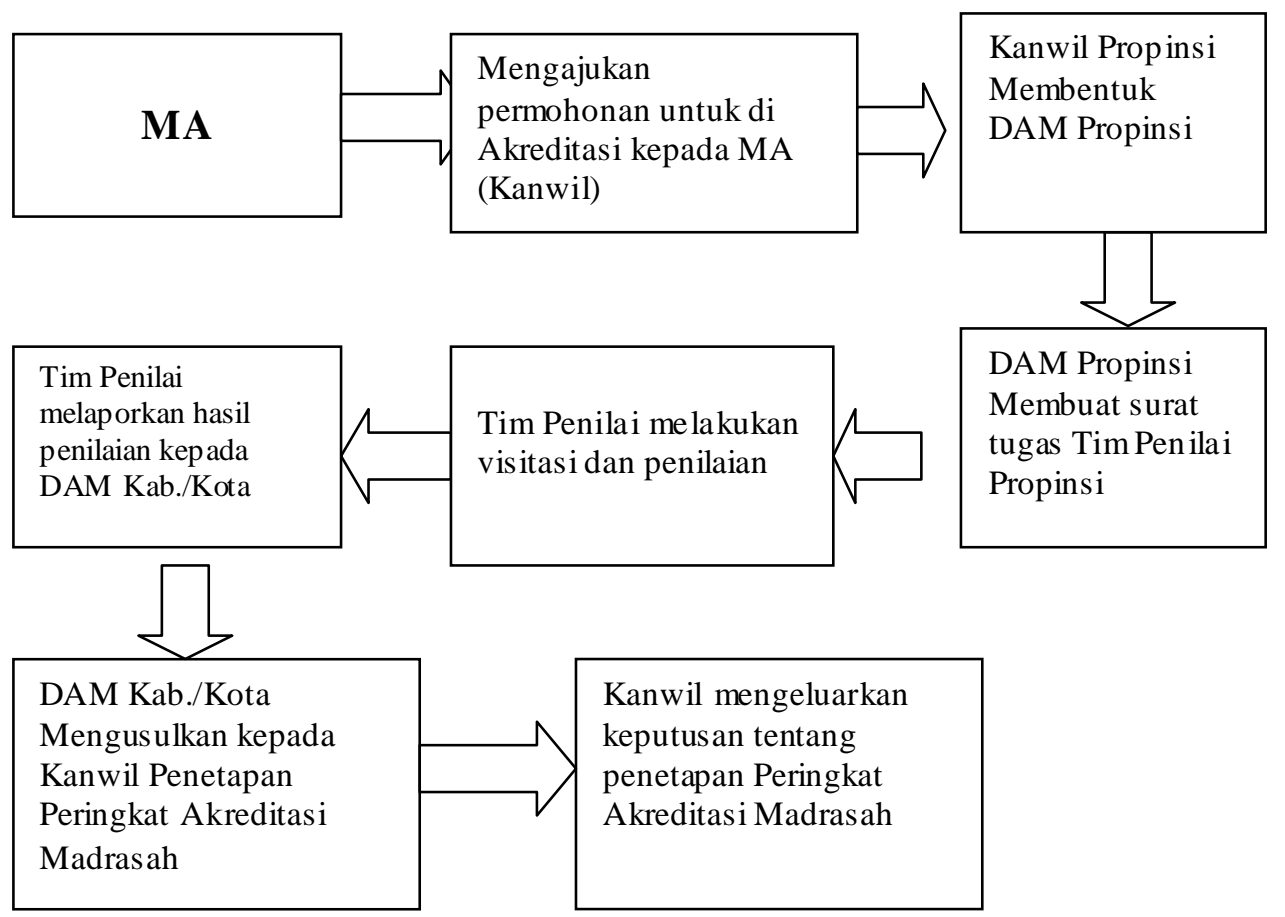

Gambar 3. Alur Pelaksanaan Akreditasi Madrasah Tingkat MA

(Depag, 2005:122-124)

\section{Kesimpulan}

Kebijakan akreditasi madrasah merupakan bagian penting dari upaya seluruh komponen bangsa dalam meningkatan mutu pendidikan nasional. Pelaksanaan akreditasi madrasah yang benar sesuai dengan pedoman dan kaidah yang ada merupakan langkah strategis semua pihak (pemerintah, Lembaga Koordinasi/Lembaga Pembina, Yayasan, Pengelola Madrasah maupun masyarakat) untuk membangun pondasi mutu/keunggulan madrasah. Hal ini dapat diketahui bahwa peran penting akreditasi antara lain: (1) Untuk mengetahui potensi madrasah dalam penyelenggaraan pendidikan. Dengan mengetahui potensi madrasah, maka kita baik pemerintah (Depag) maupun Pengelola dapat mengambil kebijakan dalam upaya meningkatkan mutu madrasah. (2) Dengan akreditasi madrasah dapat memacu pengelola madrasah untuk meningkatkan mutu pendidikan. Dengan istilah lain, tanpa akreditasi madrasah, pengelola tidak akan berusaha keras. Dengan adanya akreditasi, 
Mulyono - Akreditasi Madrasah

pengelola madrasah akan terdorong untuk bekerja keras minimal memenuhi item-item dalam akreditasi. (3) Dengan adanya akreditasi, madrasah semakin berhati-hati sekaligus bersungguh-sungguh dalam penyelenggaraan pendidikan madrasah. (4) Akreditasi akan mendorong pihak pengelola madrasah untuk merawat sarana dan prasarana misalnya gedung yang lama tak terawat kemudian dirawat kembali bahkan berusaha untuk memenuhi sarana-prasarana pendidikan secara periodik sesuai kebutuhan minimal penyelenggaraan madrasah. (5) Akreditasi madrasah akan menggugah pihak pengelola utamanya para pengurus untuk berfungsi sesuai tugas dan tanggungjawabnya bahkan dapat saling bahu-mebahu dan gotong royong bersama masyarakat maupu pihak-pihak lain dalam membantu keberhasilan penyelenggaran pendidikan madrasah. Apabila madrasah telah mampu memenuhi point-point dalam akreditasi baik secara data dan fakta maka tentunya menjadi langkah awal madrasah membangun mutu/keunggulan. Inilah signifikansi penting dari kebijakan dan pelaksanaan akreditasi madrasah.

\section{E. Daftar Pustaka}

Aziz, Abdul. 2005. Sambutan Direktur Madrasah dan Pendidikan Agama Islam di Sekolah Umum dalam Departemen Agama RI. Pedoman Akreditasi Madrasah, Jakarta: Direktorat Jenderal Kelembagaan Agama Islam, Depag RI.

Azizy, A. Qodri A. 2005. Sambutan Direktur Jenderal Kelembagaan Agama Islam dalam Departemen Agama RI. Pedoman Akreditasi Madrasah, Jakarta: Direktorat Jenderal Kelembagaan Agama Islam, Depag RI.

Baharuddin. 2008. Manajemen Pengembangan Lembaga Pendidikan Ma'arif NU. Disertasi. Malang: Universitas Negeri Malang Program Pascasarjana Program Studi Manajemen Pendidikan.

Departemen Agama RI. 2005. Pedoman Akreditasi Madrasah, Jakarta, Direktorat Jenderal Kelembagaan Agama Islam, Depag RI.

Irfan, Moh. 2001. Menyoal Sistem Akreditasi Madrasah, Jurnal Madrasah, Jakarta: Departemen Agama Pusat, Vol. 5, No. 1, 2001.

Mastuki. 2001. Seri Informasi Pendidikan Islam No. 6, Menelusuri Pertumbuhan Madrasah di Indonesia. Jakarta: Departemen Agama RI, Direktorat Jenderal Kelembagaan Agama Islam, Bagian Proyek EMIS Perguruan Agama Islam Tingkat Dasar. 
Mulyono - Akreditasi Madrasah

Mulyono. 2008. Manajemen Administrasi \& Organisasi Pendidikan. Yogyakarta: Ar-Ruzz Media, Cetakan I.

Peraturan Pemerintah Republik Indonesia Nomor 19 Tahun 2005 tentang Standar Nasional Pendidikan. 2006. Jakarta: CV. Tamita Utama.

Undang-Undang Republik Indonesia No. 20 Tahun 2003 tentang Sistem Pendidikan Nasional. 2003. Bandung: Citra Umbara.

191 Madrasah, Vol.Il No.2 Januari - Juni 2010 